\title{
ENDOLITHIC PHOTOTROPHS: EXAMPLES FROM CAVE-LIKE ENVIRONMENTS
}

\author{
Slađana Popović ${ }^{*}$, Nataša Nikolić ${ }^{2}$, Dragana Predojević́ ${ }^{2}$, Olga Jakovljević \\ Tonči Rađa ${ }^{3}$, Ana Anđelković 4 , Gordana Subakov Simićc
}

\author{
${ }^{1}$ University of Belgrade, Institute of Chemistry, Technology and Metallurgy, National Institute \\ of the Republic of Serbia, Center of Ecology and Technoeconomics, \\ Njegoševa 12, 11000 Belgrade, Serbia \\ ${ }^{2}$ University of Belgrade, Faculty of Biology, Institute of Botany and Botanical Garden \\ "Jevremovac", Takovska 43, 11000 Belgrade, Serbia \\ ${ }^{3}$ Speleological society "Špiljar", Varaždinska 53, 21000 Split, Croatia \\ ${ }^{4}$ Institute for Plant Protection and Environment, Teodora Drajzera 9, 11040 Belgrade, Serbia \\ *Corresponding author; E-mail: spopovic.bio@gmail.com
}

(Received March 9, 2021; Accepted May 15, 2021)

\begin{abstract}
Endoliths are more frequently found in extremely harsh environments, but they can inhabit mesic climate and subterranean habitats as well. Whether they are adapted to life inside rocks or do they seek refuge in this way, remains largely unknown for caves and pits. Consequently, subterranean habitats in limestone areas, were explored: three caves in Serbia (Cerjanska, Petnička and Potpeć) and one pit in Croatia (Keranova Golubinka). Sampling of rock substratum containing endoliths was performed at various distances from the entrance, at sites characterized by a lower level of light intensity. Phototrophs were separated from the rock matrix using 10\% hydrochloric acid and analyzed using light microscopy. In general, a low diversity of endoliths was observed, but representatives from Cyanobacteria, Chlorophyta and Xanthophyta were found. Cyanobacteria, more precisely coccoid forms (genera Aphanocapsa, Chroococcidiopsis, Gloeocapsa, Gloeocapsopsis, Synechococcus), were dominant. The most interesting cyanobacterial taxon, Leptolyngbya-like taxon, representing a true endolith (euendolith), was found in the Petnička Cave. This taxon and its relation to the substratum, as well as chasmoendolithic community from the Keranova Golubinka Pit, were observed using Scanning electron microscopy (SEM). It was observed that chasmoendoliths inhabit already existing surface rock cracks and fissures, while a true endolith actively bores into the substratum. Non-metric multidimensional scaling (NMDS) was performed to observe the similarity between the sampling sites. Endoliths can grow inside the rocks, making them very successful biodeteriogens, which is not a desirable trait for caves and pits that are characterized by various attractive geomorphological features that need to be preserved. Thus, considering these habitats, more attention should be paid to the endolith community in the future.
\end{abstract}

Keywords: endoliths, aerophytic Cyanobacteria and algae, cave-like environments, diversity, ecology. 


\section{INTRODUCTION}

Cyanobacteria and algae, as phototrophic microorganisms, are best known and studied from water habitats, but they can also inhabit various other niches (ALBERTANO, 2012), such as rock substrates exposed to air, that represent a specific and extreme environment for their growth and development (HAUER et al., 2015). Biofilms developing on these substrates represent an assemblage of different microorganisms embedded together in extracellular polymeric substances (ALBERTANO, 2012). The phototrophic component in biofilms growing on substrates that are exposed to light is usually very well developed, fixing carbon dioxide and providing other biofilm constituents with organic matter (ALBERTANO, 2012). The development of microorganisms on these substrates is the result of a combination of different environmental factors, substrate characteristics, as well as the mutual interaction of the microorganisms. Sometimes, owing to the seasonal variation and specific combination of environmental factors, different, physically and chemically distinctive microhabitats can be formed in the same place for one year (CASAmatta et al., 2002; Albertano, 2012; Pentecost and WhITTON, 2012; HAUER et al., 2015). One of the special and extreme aerophytic environments for life are subterranean ecosystems (CZERWIK-MARCINKOWSKA et al., 2015).

Phototrophic microorganisms that inhabit rocks are primarily divided into epilithic and endolithic Cyanobacteria and algae, where endoliths are further divided into the following groups (according to GolUBIĆ et al., 1981): chasmoendoliths, cryptoendoliths and euendolits. Epilithic Cyanobacteria and algae inhabit the surface of the rock substratum. Chasmoendolithic representatives inhabit rock cracks and fissures, i.e., live in already existing surface cracks that are connected with the outside environment. Cryptoendolithic Cyanobacteria and algae grow inside the porous rocks that already contain a network of open channels between the grains. The presence of empty spaces in rocks enables additional water and nutrient retention, thus providing a favourable habitat for these microorganisms. Euendoliths, on the other hand, are capable to actively, by physical and mechanical forces, deteriorate the rock and bore deeply into the substrate (AlberTANO, 2012; KeSHARI and ADHIKARY, 2014). Nevertheless, many researchers primarily focus on the epilithic community, as it is easy to observe and easy to sample, while endolithic growth of phototrophic microorganisms on rocks can often be overlooked (ASENCIO and ABOAL, 2000).

Endolithic microorganisms have gained scientific interest for several reasons: they have been considered as possible analogs of extraterrestrial life (i.e. life on Mars), they are studied due to their unique adaptation mechanisms to extreme and hostile conditions owing to the processes of weathering and mineral dissolution or phylogenetic reasons (HORATH and BACHOFEN, 2009). Some authors believe that endoliths play the main role in rock deterioration (undesirable changes in the quality and structure of rocks caused by microorganisms), because they provide a wider range of microhabitats that could be colonized by other organisms, sometimes even more dangerous biodeteriogens (KESHARI and ADHIKARY, 2014). This is especially important when cultural heritage or geoheritage (caves included) is observed (PANDEY, 2013). Endoliths are found worldwide, including aquatic and aerophytic habitats (HORATH and BACHOFEN, 2009), inhabiting a variety of rock types, from hard granite to porous rocks, such as limestone and sandstone (DE LOS Ríos et al., 2007). They are recorded in numerous terrestrial ecosystems that vary significantly in terms of depth, biomass, species richness and composition (DE LOS Ríos et al., 2007). Nevertheless, they are usually recorded in hot and cold deserts by many researchers, as stated below. Those are unique habitats where endoliths are adapted to very extreme environmental conditions. In such places they inhabit cracks, fissures or porous spaces between mineral grains of various substrates: anorthosite, granite, gypsum, marble, sandstone, etc. in Antarctic regions (DE LOS Ríos et al., 2014), carbonate, calcite, ignimbrite, gypsum, halite, granite, sandstone, etc. in the hyper-arid zone 
of deserts (WIERZCHOS et al., 2006; WIERZCHOS et al., 2015; MESLIER et al. 2018). Besides, cryptoendolithic algae are found to grow at a temperature of $40{ }^{\circ} \mathrm{C}$ on volcanic glass in Iceland, while in Canada, endolithic representatives have been detected at a temperature of $-19{ }^{\circ} \mathrm{C}$ on sandstone (PenteCost and Whitton, 2012). Nevertheless, endoliths have also been documented from other nondesert environments such as dolomitic rocks in the central Alps (HoRATH and BACHOFEN, 2009), travertine deposits in Yellowstone National Park, limestone cliff in Beer, Devon, United Kingdom (OLSSON-FrANCIS et al., 2010), the limestone of the Niagara Escarpment (GERRATH et al., 2000), and Maastricht limestone that was used for the construction of the 14th century O.L. Basilica in Tongeren, Belgium (SAIZJIMENEZ et al., 1990). Endoliths from cave-like environments are examined by ASENCIO and ABOAL (2000), while a detailed study from Leontari Cave was given by LAMPRINOU et al., (2009). However, the community of microorganisms in subterranean environments is still not sufficiently explored, especially in the sense of true endoliths or euendoliths.

Therefore, the goal of this study was to provide an insight into the endolithic community from subterranean environments which include three caves in Serbia and one pit in Croatia. A special attention is paid to one sample containing a true endolithic representative and its relationship with the substratum.

\section{MATERIALS AND METHODS}

\section{Study area}

The sampling was performed in three caves in Serbia (Potpeć, Cerjanska and Petnička) and one pit in Croatia (Keranova Golubinka).

Potpeć Cave, located in the Potpeć village near Užice (N 43 47' 45,1"; E $19^{\circ} 56^{\prime}$ $00,8^{\prime \prime)}$ in western Serbia, is characteristic for its monumental $50 \mathrm{~m}$ high entrance. The cave is separated into two levels - upper and lower, which is the active level (ĐUROVIĆ, 1998). Part of the lower level of the cave called Hangar, which has a typical horseshoe shape $22 \mathrm{~m}$ wide at the top and $12-16 \mathrm{~m}$ at the bottom, with a depth of about $50 \mathrm{~m}$ (LAZAREVIĆ, 1981), was chosen for sampling.

Cerjanska Cave, located near Cerje, Niš, in southeastern Serbia (N 43² 27' 07,74"; E $\left.21^{\circ} 55^{\prime} 22,81^{\prime \prime}\right)$ is an active cave, rich in various formations, more than two million years old. The main part of the Cerjanska Cave system is the Provalija ponor (often used as the synonym for Cerjanska Cave) where $6131 \mathrm{~m}$ of the cave system has been explored so far, putting this cave in the third place by length in Serbia. It has a relatively simple pattern of passages, consisting of one main passage and several lateral ones. However, this cave system consists of other parts too, of which one is Gornjekravljansko Vrelo (Pećurina) (NEŠIĆ et al., 2016) spring at Kravlje (MilanOVić, 2012).

Petnička Cave is situated near Petnica, Valjevo (N 44 14' 43,45"; E $19^{\circ}$ 56' 8,51") in the western part of Serbia. The cave consists of upper and lower part, which are connected and is characterized by rich fossil and recent typical cave fauna (ĐUROVIĆ, 1998).

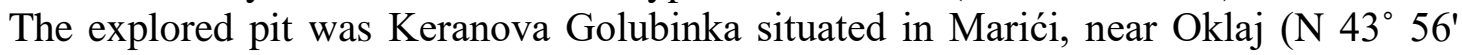
03,9"; E $\left.16^{\circ} 03^{\prime} 31,6^{\prime \prime}\right)$, Croatia. The pit is approximately $60 \mathrm{~m}$ deep, with the wide entrance area which allows light to penetrate to the deeper parts of this subterranean habitat.

All localities (Figure 1) are in limestone areas. 


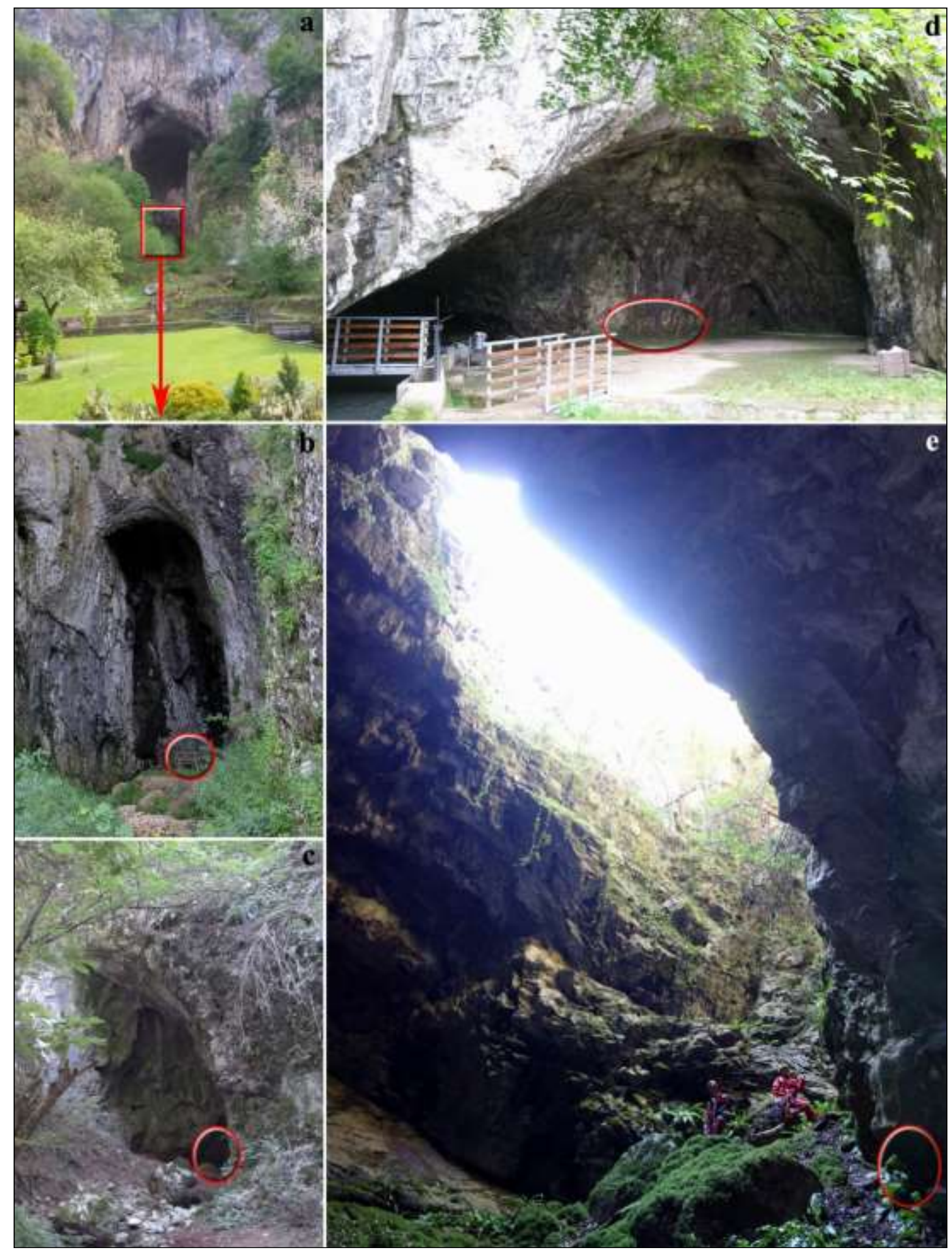

Figure 1. a - Potpeć Cave: view of the entrance from the distance; $b$ - lower level of the Potpeć Cave; c - Cerjanska Cave: spring at Kravlje; d - Petnička Cave; e - Keranova Golubinka Pit. Circles designate sampling sites.

\section{Sampling procedure}

Samples were taken during autumn 2017 from the Potpeć Cave, during summer months 2015 from Cerjanska and Petnička caves, and during spring 2020 from the Keranova Golubinka Pit.

Two samples have been collected in the Potpeć Cave, marked P1 and P2. The samples were taken at the most distant point from the entrance, approximately at the distance of $50 \mathrm{~m}$. 
The place at the cave entrance from which both samples were taken is shown in Figures 1a and 1b. Two samples were also taken from the Cerjanska Cave ( $\mathrm{C} 1$ and $\mathrm{C} 2)$ (Figure 3c). The sampling was performed at the distance of $5 \mathrm{~m}$ from the entrance. One sample (PE) was taken from Petnička Cave, from the lower part of the cave (active one), at the distance of $20 \mathrm{~m}$ from the cave entrance (Figure 1d). Also, one sample named KG was taken in Keranova Golubinka Pit (Figure 1e), from the depth of approximately $25 \mathrm{~m}$, from a shaded place.

At all sampling sites where endolithic growth of phototrophs was observed, changes in substrate color were obvious, the substrate surface was rough, but epilithic growth of phototrophs (epilithic biofilm) was absent and nothing could be sampled from the stone surface using a scalpel, as it was done in the previous works by POPOVIĆ et al. $(2015,2017)$. One such rock sample is shown on Figure 2. For this purpose, sites with noticeable deterioration of rock substratum were selected for sampling, and rock samples were collected. In such places, broken parts of rock substratum characterized by present endolithic growth usually lay on the floor of the cave. By collecting these samples without sampling from the cave wall itself, causing additional damage to the cave structures was avoided. The samples are stored in the Institute of Botany and Botanical Garden "Jevremovac" at the Faculty of Biology, University of Belgrade.

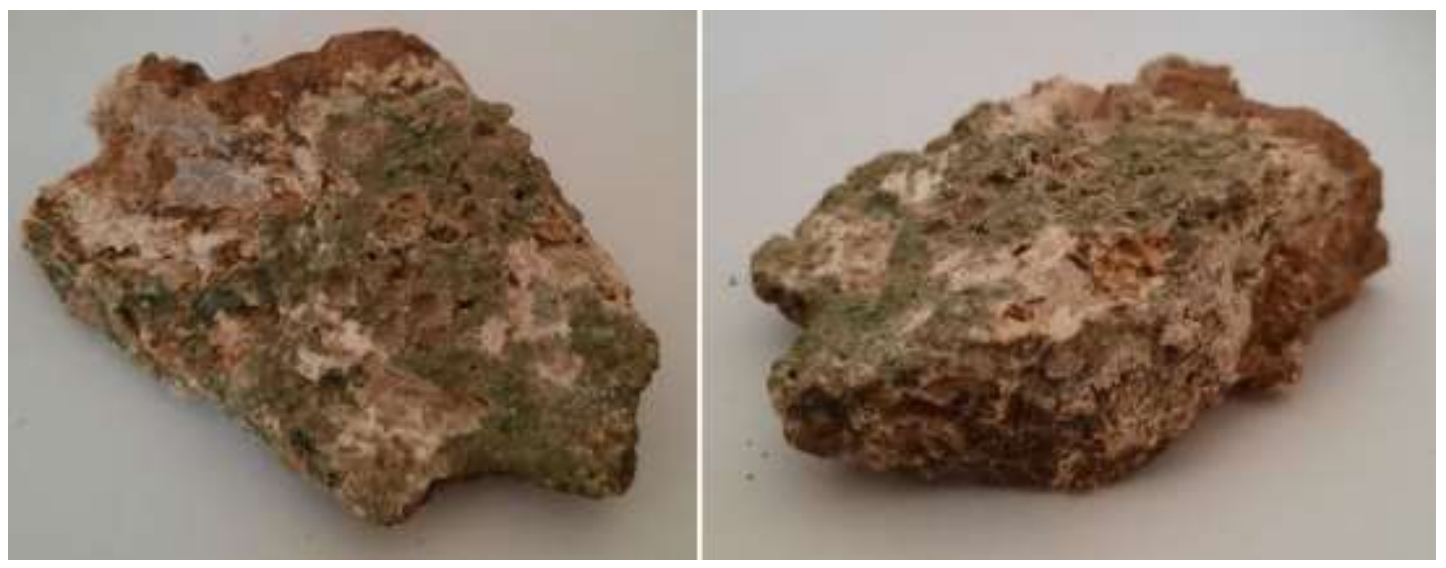

Figure 2. Examples of rock substratum with endolithic growth of phototrophs (loc. Keranova Golubinka Pit).

\section{Separation of phototrophs from the rock matrix}

The separation of endoliths from the rock matrix was done according to the method described by MATTHES-SEARS et al. (1999). Rock samples with observed endolithic growth were well washed, rinsed with distilled water and left at room temperature to dry. A nail file was used to subtly grind the rock surface, to eliminate epilithic algae if present. For each sample $100 \mathrm{ml}$ of hydrochloric acid in a concentration of $10 \%$ was poured into $250 \mathrm{ml}$ beakers. $10 \% \mathrm{HCl}$ was used because this concentration dissolves limestone rocks, but according to authors, it does not harm algal and cyanobacterial cells. Rock samples were put in beakers so that the side on which endolithic growth was noticeable was immersed in the solution of hydrochloric acid. The contact of rock and acid solution resulted in an intense reaction as a consequence of dissolving the rock matrix (limestone), with the release of carbon dioxide. Samples were left in the acid solution for $24 \mathrm{~h}$, to ensure that the rock was dissolved and phototrophs released. Only one treatment with $\mathrm{HCl}$ was performed, and no more treatments were needed. All organic material that was released from the rock precipitated at the bottom of the glass after $24 \mathrm{~h}$. The acid solution was carefully removed using Pasteur pipette, to avoid the disruption of the precipitate at the bottom of the beaker glass. After that $100 \mathrm{ml}$ of distilled water was added to the beaker to wash the sample from acid, and once 
again left for $24 \mathrm{~h}$ for phototrophs to precipitate. The procedure was repeated after $24 \mathrm{~h}$. Finally, samples were transferred to sterile $100 \mathrm{ml}$ plastic bottles and fixed with formaldehyde to a final solution concentration of $4 \%$. Using a centrifuge was avoided when rinsing the samples with distilled water, to prevent possible damage of the cyanobacterial and algal cells already treated with acid. The whole procedure was done in the digester using protective equipment.

\section{Algological analyses}

Wet mount and/or semi-permanent microscopic slides for all six samples were made in order to perform qualitative analysis of phototrophs. Wet mount microscopic slides were made when water was added and mixed with the sample, while glycerine was used for the semi-permanent slides. All was covered with the cover glass and fixed using nail polish. For the observation of microscopic slides, microscope Carl Zeiss AxioImager M.1. equipped with AxioCam MRc5 camera was used. Taxa dimensions and other parameters necessary for the proper identification were assessed in the AxioVision 4.8 software, after which identification was performed according to the standard literature (ETTL, 1978, 1980; KOMÁREK and ANAGNOSTIDIS, 1998, 2005; JOHN et al., 2003).

\section{Scanning electron microscopy}

Scanning electron microscope (SEM) observation of the two samples (from Petnička Cave (PE) and Keranova Golubinka Pit (KG)) was performed using TESCAN Mira3 XMU at the Faculty of Technology and Metallurgy, University of Belgrade and JEOL JSM-6610LV located at Faculty of Mining and Geology, University of Belgrade. The rock samples were prepared in a standard way and covered with gold using BALTEC-SCD-005 (ANONYMOUS, 2011). This non-destructive technique allowed a close view of the substratum surface, as well as phototrophs/substrate relation and connection.

\section{Light intensity}

Light intensity (LI) was measured at sampling sites in all caves using the Velleman DMV 1300 Luxmeter.

\section{Data analysis}

Non-metric multidimensional scaling (NMDS) based on Bray-Curtis distances was performed to observe the similarity between sampling sites when documented taxa are taken into account.

\section{RESULTS}

Considering all samples, a total of 12 taxa were recorded. Cyanobacteria were dominant (10 recorded taxa), with coccoid forms prevailing (7 recorded taxa). Simple trichal cyanobacterial forms were less present ( 3 taxa), while heterocytous were completely absent. Only one green algal representative was recorded, as well as one from Xanthophyta division.

The first sample from Potpeć Cave (P1) was characterized by the presence of three coccoid cyanobacterial taxa from genera Aphanocapsa, Chroococcidiopsis, and Gloeocapsa and one taxon belonging to the genus Leptolyngbya. Lower diversity was recorded in the sample P2, with exclusively coccoid cyanobacterial taxa belonging to genera Chroococcidiopsis, Gloeocapsa, and Synechococcus. In Cerjanska Cave, cyanobacterial representatives of the coccoid genus Aphanocapsa and simple trichal Leptolyngbya foveolarum were recorded in the 
first sample. Additionally, one green algae, Desmococcus olivaceus was documented too. Higher diversity was observed in the sample $\mathrm{C} 2$. Three coccoid cyanobacterial representatives were found, two from the genus Aphanocapsa and one belonging to the genus Gloeocapsopsis. A simple trichal representative, Leptolyngbya sp. has also been observed. The same green algae has been documented, as well as one representative from the Xanthophyta division. Only one representative belonging to simple trichal Cyanobacteria (Leptolyngbya-like taxon) was observed in the Petnička Cave, while exclusively coccoid Cyanobacteria were recorded in the sample taken from the Keranova Golubinka Pit (Chroococcidiopsis and Gloeocapsopsis representatives) (Table 1).

Table 1. Phototrophic microorganisms identified from cave/pit endolithic samples. P1 and P2 - Potpeć Cave; C1 and C2 - Cerjanska Cave; PE - Petnička Cave; KG - Keranova Golubinka Pit.

\begin{tabular}{|c|c|c|c|c|c|c|}
\hline PHOTOTROPHIC TAXA & P1 & $\mathbf{P 2}$ & C1 & C2 & PE & KG \\
\hline \multicolumn{7}{|l|}{ Cyanobacteria } \\
\hline Aphanocapsa muscicola (Meneghini) Wille & & & & + & & \\
\hline Aphanocapsa spp. C.Nägeli & + & & + & + & & \\
\hline Chroococcidiopsis spp. Geitler & + & + & & & & + \\
\hline Gloeocapsa sp. Kützing & + & & & & & \\
\hline Gloeocapsa biformis Ercegovic & & + & & & & \\
\hline Gloeocapsopsis sp. Geitler ex Komárek & & & & + & & + \\
\hline Leptolyngbya foveolarum (Gomont) Anagnostidis \& Komárek & & & + & & & \\
\hline Leptolyngbya spp. Anagnostidis \& Komárek & + & & & + & & \\
\hline Leptolyngbya-like taxon & & & & & + & \\
\hline Synechococcus sp. Nägeli & & + & & & & \\
\hline \multicolumn{7}{|l|}{ Chlorophyta } \\
\hline Desmococcus olivaceus (Persoon ex Acharius) J.R.Laundon & & & + & + & & \\
\hline \multicolumn{7}{|l|}{ Xanthophyta } \\
\hline Xanthophyta unidentified & & & & + & & \\
\hline
\end{tabular}

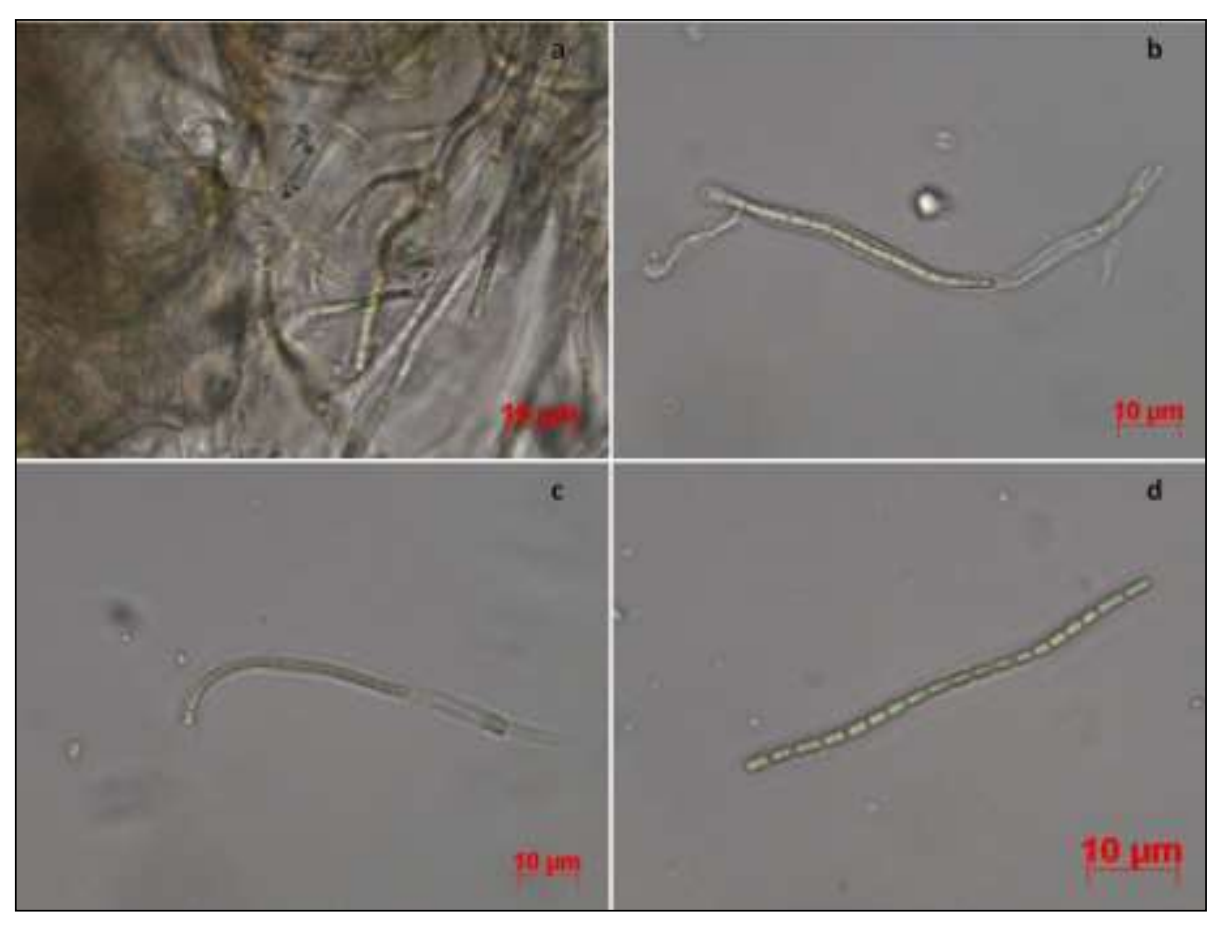

Figure 3. a-d: Leptolyngbya-like taxon from Petnička Cave (PE) observed using light microscope. 
The most interesting taxon was the cyanobacterial simple trichal representative (Leptolyngbya-like taxon) documented in the sample from the Petnička Cave (Figure 3). According to micrographs obtained using light microscopy, this taxon reminds of the genus Leptolyngbya and it is characterized with olive green trichomes constricted at cross-walls, cells that are slightly longer or longer than wide $(1,71-2,86 \times 1,55-1,79 \mu \mathrm{m})$ and colorless, to bright brown sheaths that are well-developed (Figure 3 a-d). Sheaths can be seen in all micrographs, with the exception of Figure 3d. The relation of this taxon and substratum was better observed using SEM.

Sample from the Keranova Golubinka Pit observed by SEM shows chasmoendoliths in connection with the substratum, while one from the Petnička Cave demonstrates a true endolith (Figure 4). On the SEM micrographs of the sample from the Keranova Golubinka Pit (Figure 4, a-b), a close connection between the coccoid cyanobacterial representatives (Chroococcidiopsis spp. and Gloeocapsopsis sp.) and rock surface (cracks and fissures) can be observed. Red arrows point to the aggregates of coccoid Cyanobacteria embedded in extracellular polymeric substances (EPSs). On the other hand, SEM micrographs of the sample from the Petnička Cave (Figure $4 \mathrm{c}$-d) provide a closer look at how limestone substratum and the observed Leptolyngbya-like taxon are related. Limestone captured with SEM shown in Figure 4c demonstrates signs and imprints of this taxon, as a consequence of its euendolithic growth and activity that can be seen all over the substrate, such as the points marked with red arrows. The taxon (marked with red arrows) in association with the substratum is shown in Figure 4f. This SEM micrograph (Figure 4f) allows us to observe one individual (on the right) enveloped by sheath, and the other (on the left) without sheath, where the cells and constrictions between them are evident. For both individuals, only part of the trichome is emerging from the limestone substratum.

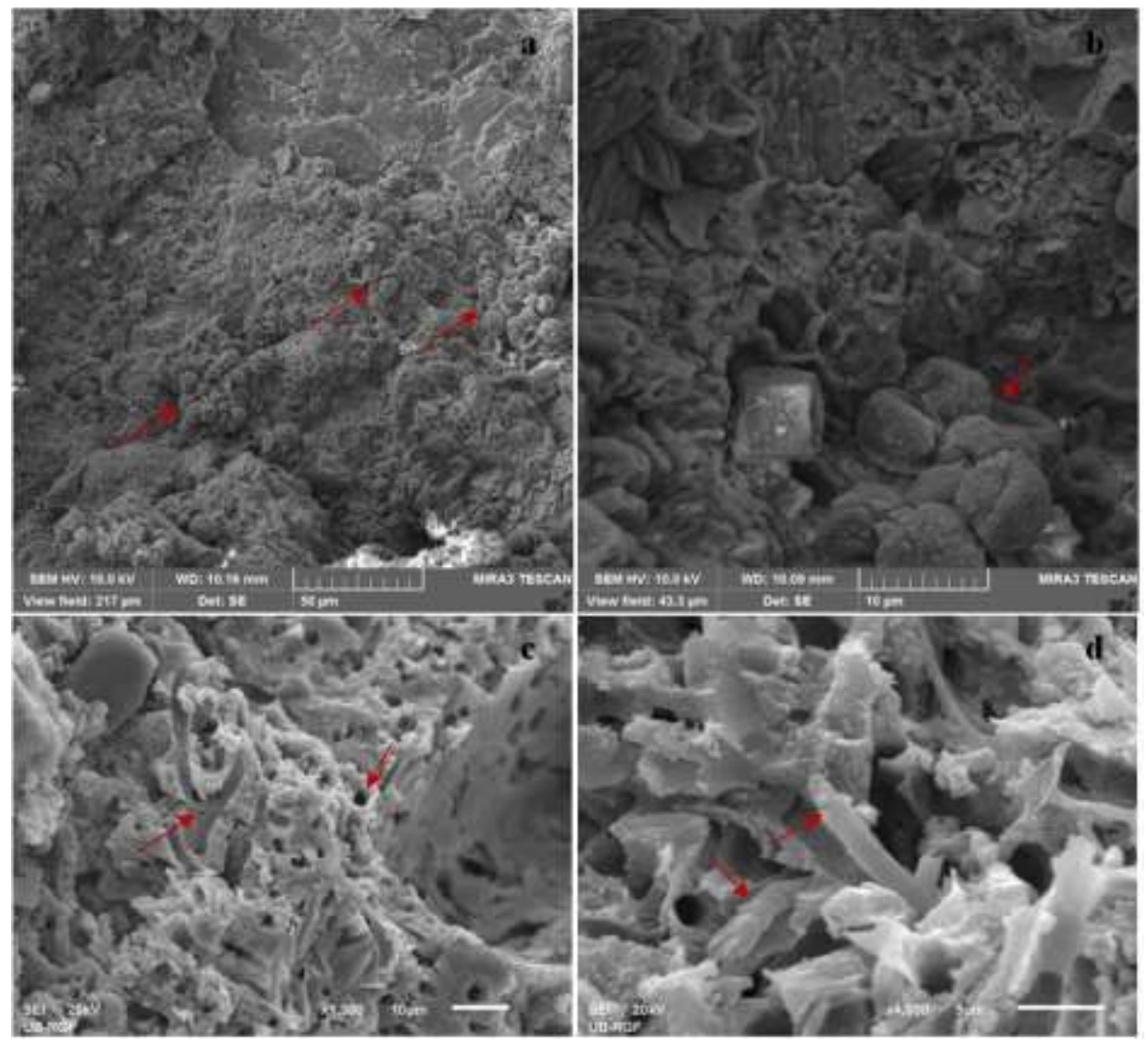

Figure 4. a-b: SEM micrographs of the sample from the Keranova Golubinka Pit (association of chasmoendoliths and rock); c-d: SEM micrographs of the sample from the Petnička Cave showing signs of euendolithic growth. 
Light intensity (LI) values were similar among sampling sites. At sites where P1 and P2 samples in Potpeć Cave were taken, light intensity of 149 Lux and 192 Lux was measured. In Cerjanska Cave, LI of 77 Lux and 68 Lux was measured at places where C1 and C2 samples were taken, respectively, while in Petnička Cave the value of LI at sampling site was 98 Lux. We do not have the data from the Keranova Golubinka Pit.

According to the NMDS (Figure 5), and taking into account the recorded taxa, the most similar sampling sites are $\mathrm{P} 2$ and $\mathrm{KG}$, as well as $\mathrm{C} 1$ and $\mathrm{C} 2$. Even though $\mathrm{P} 1$ has separated from these two groups, PE has shown to be the most distant, when compared to all other sampling sites.

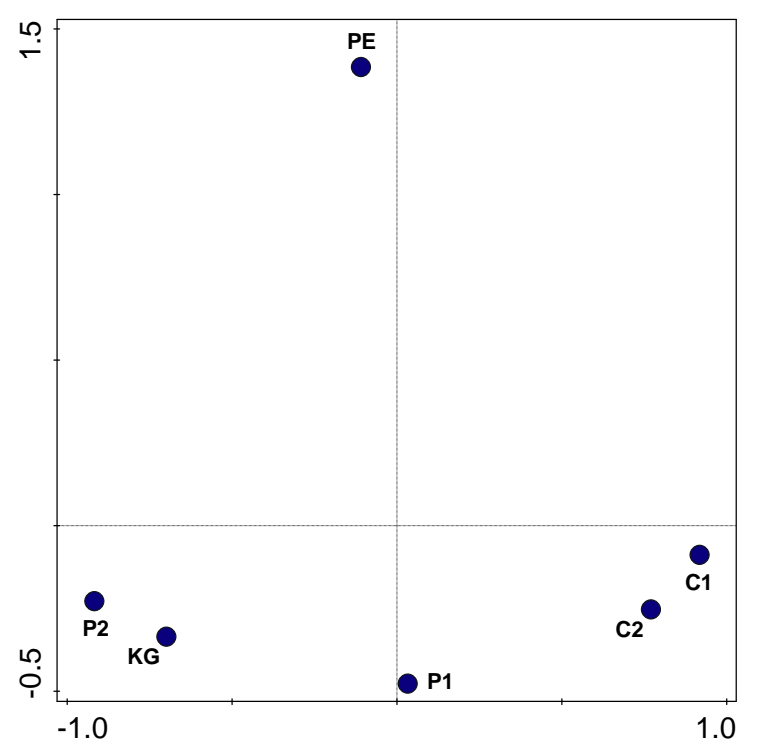

Figure 5. Non-metric multidimensional scaling (NMDS) showing similarity/dissimilarity between the sampling sites.

\section{DISCUSSION}

When discussing aerophytic Cyanobacteria and algae in general, identification of these taxa can be rather problematic. This applies also to those representatives which inhabit various stone surfaces, where different life forms, such as epiliths and endoliths are included. Morphology of the endoliths could be slightly different when compared to the morphology of the same taxa living as epiliths, due to their adaptations on endolithic life. This can lead to problems in the proper identification to the species level, based on morphological and ecological traits. Consequently, the identification of endolithic Cyanobacteria and algae based on identification keys was mostly possible only to the genus level in this study. Futhermore, the treatment of samples with an acid solution has also contributed to this. Even though MATTHES-SEARS et al. (1999) reported that 10\% acid solution used for the separation of phototrophs from the rock matrix does not affect the cell morphology of Cyanobacteria and algae, slight changes which have influenced proper identification have been evident in the representatives identified only to the genus level (Table 1).

Cyanobacteria are found to be the dominant phototrophs, with coccoid forms prevailing (genera Aphanocapsa, Chroococcidiopsis, Gloeocapsa, Gloeocapsopsis, Synechococcus), with considerably less simple trichal cyanobacterial forms present (mostly genus Leptolyngbya) (Table 1). ASENCIO and ABOAL (2000) have recorded Gloeocapsa, Chroococcidiopsis and Leptolyngbya to be the most diversified chasmoendolithic genera in 
cave-like environments. LAMPRINOU et al., (2009) reported endolithic assemblages that formed monospecific patina (Chlorogloea sp.), or mixed populations that consist of chasmoendolithic and/or cryptoendolithic species, such as Aphanocapsa muscicola, Chroococcus turgidus, Gloeocapsa biformis, Chroococcus spelaeus, and Leptolyngbya gracillima. Both ASENCIO and ABOAL (2000) and LAMPRINOU et al. (2009) mentioned coccoid and simple trichal cyanobacterial forms. Although Chroococcidiopsis and Gloeocapsa are frequently found in cave-like environments, these genera are also found in many other habitat type, such as those with mesic climates (SAIZ-JIMENEZ et al., 1990; GERRATH et al., 2000), but also those with harsh climates, such as hot and cold deserts (WIERZCHOS et al. 2006; BUDEl et al. 2008; OlSSON-FRANCIS et al., 2010; WIERZCHOS et al. 2015; MESLIER et al. 2018). The fact that Chroococcidiopsis has been observed in almost every endolithic habitat leads to the conclusion that representatives of this genus play a very important role in these microecosystems. Chroococcidiopsis representatives have a remarkable ability to withstand the lethal effects of desiccation, as the thick multilayered envelope, rich in polysaccharides surrounding the cell cytoplasm and the colonies of organisms acts as a shield, protecting them from desiccation and extreme external conditions (BÜDEL et al., 2008).

Cyanobacteria are detected in significant abundance in almost all endolithic habitats (DE LOS Ríos et al., 2007). While they are extremely dominant in harsh environments, algal representatives are more often recorded in less severe ones (GERRATH et al., 2000; QUESADA AND VINCENT, 2012; WIERZCHOS et al., 2015; MESLIER et al., 2018). Even though Cyanobacteria and green algae are mentioned as the most widespread endoliths, red algae can also be found (ANTONY et al., 2012), as well as Xanthophyceae (GERRATH et al., 2000).

By taking into account endolithic communities from subterranean environments explored in this study, we can conclude that an overall low diversity of endoliths is observed, compared to, epilithic communities explored in cave environments (i.e. POPOVIĆ et al., 2015, 2017). Low and rather restricted diversity of endoliths is frequently observed in places with harsh climates - cold and hot deserts and semideserts (HORATH and BACHOFEN, 2009; QUESADA and VINCENT, 2012). Nevertheless, endolithic communities should be more diverse in non-desert environments (GERRATH et al., 2000). Despite the overall low diversity recorded in this study, in addition to Cyanobacteria, the presence of Chlorophyta and Xanthophyta is also noted. Contrary to the general opinion that diversity of endoliths is still low overall, some authors demonstrate astonishingly high diversity of endolithic Cyanobacteria, with representatives of the genera Cyanosaccus, Hormathonema, Hyella, Solentia, Plectonema, Kyrthutrix, Schizotrix, Iyengariella, and Mastigocoleus being considered true euendoliths (RAMÍREZ-REINAT, 2010).

Water and nutrient availability, temperature, light, UV radiation, and predation are considered to be the most important factors controlling or affecting the life of microorganisms on/in rocks (ANTONY et al., 2012), with liquid water as a limiting factor (QUESADA and VINCENT, 2012; DE LOS Ríos et al., 2014). Once water becomes available, its retention is crucial and is dependent on the physical structure and water-adsorbing capacity of the lithic substrate, but also on the presence and amount of extracellular polysaccharides produced by endolithic microorganisms, especially Cyanobacteria (ALBERTANO, 2012; QUESADA and ViNCENT, 2012; DE LOS Ríos et al., 2014). Higher levels of air humidity in caves and the presence of seeping water can positively influence the development of microorganisms on and in stone surfaces (MULEC et al.. 2008). When nutrients are considered, lithic substrates are characterized as oligotrophic habitats, as are also the cave-like environments in general. Endoliths are considered to be adapted to additionally extract some nutrients from the rock, even though their main source of nutrients is of allochthonous origin (GORBUSHINA, 2007; ANTONY et al., 2012). Temperature can be an important factor which influences the development of endoliths, and endoliths are most frequently found at places with extremely high or low air temperatures, and its rapid fluctuations, finding favourable and protected place 
inside the rock (ANTONY et al., 2012; QuESADA and VinCENT, 2012; De Los Ríos et al., 2014). Contrary to this, entrances of subterranean habitats have more stable environmental conditions, even though they are influenced by the outside climate (LAMPRINOU et al., 2012). Light is a driving factor for the development of phototrophic organisms. Even though according to some authors there is no evidence of the relationship between the depth of the endolithic colonization and light penetration (ANTONY et al., 2012; QUESADA and VINCENT, 2012), light penetration into the rock, which is dependent on the rock type, is still considered to be closely correlated with the depth on which phototrophs develop. Often, if the light intensity is high, as a consequence of the irradiance transmission, different colored bands (composed of different groups of microorganisms at varying depths) that run parallel to the rock surface can appear (SAIZ-JIMENEZ et al., 1990; HORATH and BACHOFEN, 2009; QUESADA and VINCENT, 2012). Light intensity at cave entrances is variable during the day, but it has considerably lower values than in outside environments. Light intensity measured at the sampling sites in this study was the lowest in Cerjanska Cave, and the highest in Potpeć Cave. However, the differences between these values were not high and significant and in general there was sufficient light for the development of phototrophs. Due to a lower light intensity when compared to the outside environment, our samples were characterized by green coloration at the surface part of the substratum. It is interesting that DE LOS Ríos et al. (2014), observing sample with different colored bands, reported that the lowest layer was composed of Cyanobacteria. The presence of Cyanobacteria in the lowest layer may point to their ability to grow at lower light levels, which can be related to subterranean habitats explored in this study, where Cyanobacteria dominated as endoliths. According to some authors, the type of substrate can also be of importance in the development of microorganisms (MAZINA and MAXIMOV 2011), while according to others, rock chemistry is usually not an essential driver and whichever substrate is colonized, physical rock properties, space available for colonization, and water retention capabilities are the most important factors which play a significant role in shaping the endolithic community (MESLIER et al., 2018). However, limestone is favourable for the development of Cyanobacteria due to higher $\mathrm{pH}$ (PANTAZIDOU and RousSOMOUSTAKAKI. 2005), which coincides with cyanobacterial dominance in this study.

Scanning electron microscopy is a non-destructive method used for detailed observation of the sample surface, morphology, texture, size and shape of particles, their orientation and type of connection. The sample from Keranova Golubinka Pit (Figure 2) has demonstrated a chasmoendolithic community related to the surface cracks of the rock substratum. On the other hand, endolithic cyanobacterial representative, Leptolyngbya-like taxon, that was found growing inside the limestone substrate of the Petnička Cave most likely belongs to true euendoliths - endoliths that actively bore into the rock. The record of euendolith cyanobacterial representatives is not unexpected in limestone areas (LAMPRINOU et al., 2009). Compared to others, carbonate substrate is soft and gives satisfying protection to microorganisms that are capable to inhabit it. Few mechanisms of microorganisms boring into the rock have been suggested. According to one assumption (RAMíREZ-REINAT, 2010), euendoliths secrete compounds that are characterized with low $\mathrm{pH}$ value. However, autotrophs use $\mathrm{CO}_{2}$ in photosynthesis, thus increasing $\mathrm{pH}$ of their environment. Therefore, it is believed that they bore into the rock only during the night, or that they photosynthesize only when they are outside the carbonate matrix. A suggested mechanism could be interesting, but authors agree that it would be very energy-demanding for the microorganism itself. The second mechanism worth mentioning is based on the removal of calcium ions by transport enzymes. Microorganisms can adsorb calcium ions from interstitial space (space between cells and minerals), leading to lower quantities of calcium in substrate and its weakening. They adsorb calcium ions on one side of the cell, move them through the cell and secrete 
them on the opposite side. This mechanism of calcium transport is exactly what allows euendoliths to actively bore into the substratum (RAMÍREZ-REINAT, 2010).

NMDS diagram separated a group of samples based on the recorded taxa. First group is composed of $\mathrm{P} 2$ and $\mathrm{KG}$ that are characterized by the presence of only coccoid cyanobacterial forms (representatives of Chroococcidiopsis, Gloeocapsa, Gloeocapsopsis and Synechococcus). P1 was separated, as in this sample, coccoid, as well as simple trichal cyanobacterial representatives, were recorded (genera Aphanocapsa, Chroococcidiopsis, Gloeocapsa and Leptolyngbya). $\mathrm{C} 1$ and $\mathrm{C} 2$ that form a separate group are not only characterized by the presence of coccoid and simple trichal Cyanobacteria (genera Aphanocapsa, Gloeocapsopsis, Leptolyngbya), but are also the only sites where green algae Desmococcus olivaceus was found. PE was the most distant of all, since only one sample of a trichal cyanobacterial taxon whose identification was not certain was found here.

\section{CONCLUSIONS}

Endolithic phototrophs are not explored enough, especially in habitats where they are expected to develop to a lesser extent, such as subterranean ones. In this study, they are explored from three caves in Serbia (Cerjanska, Petnička and Potpeć) and one pit in Croatia (Keranova Golubinka), i.e. all from places characterized by lower level of light intensity and a little bit more uniform environmental conditions. In general, low diversity of endoliths was observed, with Cyanobacteria (mostly coccoid forms, genera Aphanocapsa, Chroococcidiopsis, Gloeocapsa, Gloeocapsopsis, Synechococcus) being dominant. The most interesting cyanobacterial taxon was one euendolith (Leptolyngbya-like taxon) which association with the substratum, together with chasmoendolithic community from other locality, is observed using SEM. Even though a small number of endolithic samples was found at examined localities, this community should not be neglected. Considering subterranean environments that are rich in various morphological features attractive to tourists, development of phototrophic community, especially euendolithic one, is not desirable. In this study, endoliths are explored mainly from the cave/pit entrances, but they can be also present inside of attractive and illuminated tourist caves. Thus, more attention should be paid to this community in the future and monitoring of such sites needs to be performed continuously.

\section{Acknowledgements}

This work was financially supported by the Ministry of Education, Science and Technological Development of the Republic of Serbia (Grant No. 451-03-9/2021-14/200026, Grant No. 451-03-9/2021-14/ 200178 and Grant No. 451-03-9/2021-14/200010). The authors would like to thank Željko Radovanović from the Innovation center of the Faculty of Technology and Metallurgy, University of Belgrade, for providing SEM micrographs of the sample from Keranova Golubinka.

\section{References:}

[1] Albertano, P. (2012): Cyanobacterial biofilms in monuments and caves. Chapter 11. In: Whitton, B.A. (ed) Ecology of Cyanobacteria II: their diversity in space and time. Springer, Netherlands $753 \mathrm{pp}$ 
[2] AnONYMous (2011) Brošura SEM LAB. Laboratorija za skenirajuću elektronsku mikroskopiju, Univerzitet u Beogradu, Rudarsko-geološki fakultet, Zgrada Hemijskog fakulteta, Studentski trg 12-16, Beograd, Prvi suteren, soba 242. [in Serbian]

[3] Antony, C.P., Cockell, C.S., Shouche, Y.S. (2012): Life in (and on) the rocks. Journal of Bioscience 37 (1): 3-11. doi: 10.1007/s12038-012-9184-8

[4] Asencio, A.D., Aboal, M. (2000): A contribution to knowledge of chasmoendolithic algae in cave-like environments. Algological Studies 98: 133-151.

doi: 10.1127/algol_stud/98/2000/133

[5] BÜDEl, B., BendiX, J., Bicker, F.R., Allan, GreEN, T.G. (2008): Dewfall as a water source frequently activates the endolithic cyanobacterial communities in the granites of Taylor Valley, Antarctica. Journal of Phycology 44 (6): 1415-1424.

doi: 10.1111/j.1529-8817.2008.00608.x

[6] Casamatta, D.A., Verb, R.G., Beaver, J.R., Vis, M.L. (2002): An investigation of the cryptobiotic community from sandstone cliffs in Southeast Ohio. International Journal of Plant Science 163 (5): 837-845. doi: 10.1086/341514

[7] Czerwik-Marcinkowska, J., Wojciechowska, A., Massalski, A. (2015): Biodiversity of limestone caves: aggregations of aerophytic algae and cyanobacteria in relation to site factors. Polish Journal of Ecology 63 (4): 481-499.

doi: 10.3161/15052249PJE2015.63.4.002

[8] De los Ríos, A., Grube, M., Sancho, L.G., Ascaso, C. (2007): Ultrastructural and genetic characteristics of endolithic cyanobacterial biofilms colonizing Antarctic granite rocks. - FEMS Microbiology Ecology 59 (2): 386-395.

doi: 10.1111/j.1574-6941.2006.00256.x

[9] De los Ríos, A., Wierzchos, J., Ascaso, C. (2014): Synthesis The lithic microbial ecosystems of Antarctica's McMurdo Dry Valleys. Antarctic Science 26 (5): 459-477. doi: $10.1017 /$ S0954102014000194

[10] Đurović, P. (1998): Speleological atlas of Serbia, Serbian Academy of Science and Arts, Belgrade, 290. [in Serbian with English summary]

[11] ETTL H. (1978): Xanthophyceae. 1. Teil. In: Ettl, H., Gerloff, J., Heynig, H. (eds.) Süßwasserflora von Mitteleuropa, 3. Gustav Fischer Verlag, Jena 500 pp.

[12] ETTL H. (1980): Xanthophyceae. 2. Teil. In: Ettl, H., Gerloff, J., Heynig, H. (eds.) Süßwasserflora von Mitteleuropa, 4. Gustav Fischer Verlag, Jena 530pp.

[13] Gerrath, J.F., Gerrath, J.A., Matthes, U., Larson, D.W. (2000): Endolithic algae and cyanobacteria from cliffs of the Niagara Escarpment, Ontario, Canada. Canadian Journal of Botany 78 (6): 807-815. doi: 10.1139/b00-042

[14] Golubić, S., Friedmann, I., Schneider, J. (1981): The lithobiontic niche, with special reference to microorganisms. Journal of Sedimentary Petrology 51: 475-478.

[15] GorbushinA, A.A. (2007): Life on the rocks. Environmental Microbiology 9 (7): 16131631. doi: 10.1111/j.1462-2920.2007.01301.x

[16] Hauer, T., Mühlsteinova, R., Bohunická, M., Kaštovský, J., Mereš, J. (2015): Diversity of cyanobacteria on rock surfaces. Biodiversity and Conservation 24: 759779. doi: 10.1007/s10531-015-0890-z 
[17] Horath, T., BaCHOFEN, R. (2009): Molecular Characterization of an Endolithic Microbial Community in Dolomite Rock in the Central Alps (Switzerland). Microbial Ecology 58 (2): 290-306. doi: 10.1007/s00248-008-9483-7

[18] John, D.M., Whitton, B.A. BrooK, A.J. (2003): The Freshwater Algal Flora of the British Isles: an Identification Guide to Freshwater and Terrestrial Algae. Cambridge University Press, UK: 702pp.

[19] Keshari, N., ADHIKARY, S.P. (2014): Diversity of cyanobacteria on stone monuments and building facades of India and their phylogenetic analysis. International Journal of Biodeteriation and Biodegradation 90: 45-91. doi: 10.1016/j.ibiod.2014.01.014

[20] KomáreK, J., Anagnostidis, K. (1998): Cyanoprokariota. 1. Teil: Chroococcales. In: Ettl, H., Gärtner, G., Heynig, H., Mollenhauer, D. (eds.) Süßwasserflora von Mitteleuropa. Spektrum Akademischer Verlag, Heidelberg, Berlin: 212 pp.

[21] Komárek, J., Anagnostidis, K. (2005): Cyanoprokaryota. 2. Teil: Oscillatoriales. In: Büdel, B., Gärtner, G., Krienitz, L., Schagerl, M. (eds.) Süßwasserflora von Mitteleuropa. Spektrum Akademischer Verlag, Heidelberg, Berlin: 759 pp.

[22] LAmprinou, V., PANTAZidou, A., PAPAdogiannaki, G., RAdEA, C., EcOnOMOU-Amilli, A. (2009): Cyanobacteria and associated invertebrates in Leontari Cave, Attica (Greece). Fottea 9: 155-164. doi: 10.5507/fot.2009.014

[23] Lamprinou, V., Danielidis, D.B., Economou-Amilli, A., Pantazidou, A. (2012): Distribution survey of Cyanobacteria in three Greek caves of Peloponnese. International Journal of Speleology 41 (2): 267-272. doi: 10.5038/1827-806X.41.2.12

[24] LaZarević, R. (1981): Potpeć Cave RO "D. Tucovic", Užice. [in Serbian with English summary]

[25] Matthes-Sears, U., Gerrath, J.A., Gerrath, J.F., Larson, D.W. (1999): Community structure of epilithic and endolithic algae and cyanobacteria on cliffs of the Niagara Escarpment. Journal of Vegetation Science 10 (4): 587-598. doi: 10.2307/3237193

[26] Mazina, S.E., Maximov, V.N. (2011): Photosynthetic Organism Communities of the Akhshtyrskaya Excursion Cave. Moscow University Biological Sciences Bulletin 66 (1): 37-41. doi: 10.3103/S009639251101007X

[27] Meslier, V., Casero, M.C., Dailey, M., Wierzchos, J., Ascaso, C., Artieda, O., DiRugGiero, J. (2018): Fundamental drivers for endolithic microbial communities asemmblies in the hyper-arid Atacama Desert. Environmental Microbiology 20 (5): 1765-1781. doi: 10.1111/1462-2920.14106

[28] Milanović, S. (2012): Speleology and speleological diving in karst hydrogeology. Faculty of Mining and Geology, Belgrade: 307 pp. [in Serbian with English summary]

[29] Mulec, J., Kosi, G., VRhovŠEK, D. (2008): Characterization of cave aerophytic algal communities and effects of irradiance levels on production of pigments. Journal of Cave and Karst Studies 70 (1): 3-12. doi: 10.1515/9783110339888-014

[30] NeŠić, D., Jović, D., Janković, M., KličKović, M., Nedeljković, D., Stojković, Z., Pavićević, D., Zatezalo, A., Popović, M., Branković, S., Grubač, B., Mihailović, D., Panić, N., Petrović, S., Gočmanac, S. (2016): Natural Monument Cerjanska Pećina: surroundings, natural history, protection. Institute for Nature Conservation of Serbia, Belgrade: 183 pp. 
[31] Saiz-Jimenez, C., Garcia-Rowe, L.J., Garcia del Cura, M.A., Ortega-Calvo, J.J., Roekens, E., VAn GrieKen, R. (1990): Endolithic Cyanobacteria in Maastricht Limestone. Science of Total Environment 94 (3): 209-220.

doi: 10.1016/0048-9697(90)90171-P

[32] Olsson-Francis, K., DE LA TORRE, R., Cockell, C.S. (2010): Isolation of Novel Extreme-Tolerant Cyanobacteria from a Rock-Dwelling Microbial Community by Using Exposure to Low Earth Orbit. Applied Environmental Microbiology 76 (7): 21152121. doi: 10.1128/AEM.02547-09

[33] PANDEY, V.D. (2013): Rock-dwelling cyanobacteria: survival strategies and biodeterioration of monuments. International Journal of Current Microbiology and Applied Science 2 (12): 519-524.

[34] Pantazidou, A., Roussomoustakaki, M. (2005): Biodiversity and ecology of cyanobacteria in a variety of hypogean ecosystems (Greece). 14th International Congress of Speleology. 21-28 August 2005, Kalamos, Hellas.

[35] Pentecost, A., Whitton, B.A. (2012): Subaerial Cyanobacteria. Chapter 10. In: Whitton, B.A. (ed) Ecology of Cyanobacteria II: their diversity in space and time. Springer, Netherlands: $753 \mathrm{pp}$

[36] Popović, S., Subakov Simić, G., Stupar, M., Unković, N., Predojević, D., JovanoVIĆ, J., LJALJEVIĆ GRBIĆ, M. (2015): Cyanobacteria, algae and microfungi present in biofilm from Božana Cave (Serbia). International Journal of Speleology 44 (2): 141149. doi: 10.5038/1827-806X.44.2.4

[37] Popović, S., Subakov Simić, G., Stupar, M., Unković, N., Krunić, O., Savić, N., LJALJEVIĆ GRBIĆ, M. (2017): Cave biofilms: characterization of phototrophic cyanobacteria and algae and chemotrophic fungi from three caves in Serbia. Journal of Caves and Karst Studies 79 (1): 10-23. doi: 10.4311/2016MB0124

[38] Ramírez-Reinat E. (2010): How Cyanobacteria Bore. PhD thesis, Arizona State University.

[39] Quesada, A., Vinsent, W.F. (2012): Cyanobacteria in the Cryosphere: Snow, Ice and Extreme Cold. Chapter 14. In: Whitton, B.A. (ed) Ecology of Cyanobacteria II: their diversity in space and time. Springer, Netherlands: $753 \mathrm{pp}$.

[40] Wierzchos, J., Ascaso, C., Mckay, C.P. (2006): Endolithic Cyanobacteria in halite rocks from the hyperarid core of the Atacama Desert. Astrobiology 6 (3): 415-22.

[41] Wierzchos, J., Di Ruggiero, J., Vítek, P., Artieda, O., Souza-Egipsy, V., ŠKaloud, P., Tisza, M., Davila, A.F., Vílchez, C., Garbayo, I., Ascaso, C. (2015): Adaptation strategies of endolithic chlorophototrophs to survive the hyperarid and extreme solar radiation environment of the Atacama Desert. Frontiers in Microbiology 6: 934. doi: 10.3389/fmicb.2015.00934 